\title{
Craig Lundahl Responds
}

To the Editor:

Michael Perry suggests that my caution against ignoring Biblical and Mormon prophecies and the predictive aspects of some near-death experiences (NDEs) because of the potential for deadly serious consequences should be disregarded. He offers as his rationale that Joseph Smith and contemporary NDErs simply worried about the immediate future of our civilization and clothed their worries in the traditional apocalyptic dress found in the collective Western subconscious, and that Jesus of Nazareth used this type of image as a good metaphor to describe the cataclysmic sociopolitical events of His time.

Did Smith project his worries about the future of civilization in the prophecies found in The Doctrine and Covenants (1979)? Supposedly, most of the sections of this book came to Smith by direct revelation and the words were those of the resurrected Jesus of Nazareth Himself. Twelve persons bore witness that it was spiritually manifested to them that the record was not the words of Smith. Also, many of those book sections were recorded by persons other than Smith. However, probably more convincing to scientific scrutiny is the fact that Section 45 of The Doctrine and Covenants contains information that is not mentioned or clearly explained in the other scriptural account (Matthew 24) of what Jesus said regarding His second coming to the world (Watch and Be Ready, 1994, pp. 134-166). This suggests that The Doctrines and Covenants is more than just the traditional apocalyptic dress.

Regarding contemporary NDErs, Perry seems to be saying that the NDErs who reported having prophetic visions never had them at all, but that these visions were falsified and used by the NDErs as an avenue in their attempt to change the disastrous course of our civilization. This means that at least 16 subjects in Kenneth Ring's study of prophetic visions $(1982,1984)$, who were unknown to each other and from different 
locations, all had the same motive and falsified their visions to the researcher. However, Ring wrote that their reports of the future events they saw in their prophetic visions were highly consistent from person to person, suggesting the unlikelihood of this occurring $(1984$, p. 194). Margot Grey's (1985) independent study of prophetic visions tended to confirm Ring's earlier findings, raising further doubts about Perry's supposition. The prophetic visions also spoke of volcanic activity and economic breakdowns that were not specifically mentioned in the holy writ of the Bible or The Doctrine and Covenants, placing these prophetic visions beyond the traditional apocalyptic dress.

Was Jesus of Nazareth projecting his worries about the future of civilization and describing just the cataclysmic sociopolitical events of His time? That is apparently not true according to Smith's inspired translation of the gospel of Matthew found in The Pearl of Great Price (1979) and The Doctrine and Covenants. In Smith's translation of Matthew 21, a transition is made from the generation of A.D. 33-70 to a description of later generations, especially the generation living just prior to Jesus of Nazareth's second advent. The same transition also occurs in Verse 24 of The Doctrine and Covenants, Section 45. Despite modern Biblical scholarship, both of these scriptural sources clarify that Jesus was not simply describing the cataclysmic sociopolitical events of His time.

Perry's letter speaks of dated prophecy always failing. It is true that subjects in John Audette's NDE study (1982) and in Ring's investigation (1984, pp. 194 and 205) most frequently cited the year 1988 as the year that would be the end of time. But it is also true that the near-death experiencers who had the prophetic visions generally agreed that there were no fixed dates for specific events to occur in the future, even though some were told of a date or felt something would happen at a particular time unless some mitigating circumstances intervened. This is entirely consistent with holy prophecies that rarely specify an exact date when a prediction is to come true. Usually the period and the accompanying circumstances are given, but not a precise date.

However, the prediction by the NDE prophetic visionaries that the time for the end of time would come in the late 1980s was correct. Unbeknownst to Ring or Grey, and probably to most if not all of the NDE visionaries, was the intervention of Mary (a mitigating circumstance), the Mother of Jesus, who obtained from the Lord Jesus Christ a delay in the end of time and its attending events. She actually intervened in 1988, again in 1990, and on other occasions (Marian Movement of Priests, 1996, pp. 611 and 713). 
Perry does not specify exactly what he means by dated prophecy, but I assume he means a prophecy with a specific date. The only predictions of the second advent of Jesus Christ, besides the 1988 date in my article, are found in a statement from Ring's investigation about the future scenario of the Earth not extending much beyond the beginning of the 21st century before an era of peace, and one found in The Doctrine and Covenants stating that Jesus Christ's coming will be in the beginning of the seventh thousand years. Neither of these prophecies could be classified as prophecies with specific dates. Surprisingly, though, both of these prophecies are in agreement and pertain to the first part of early period of the 21st century. According to The Doctrine and Covenants 77:13, Jesus Christ's second advent will occur after the opening of the seventh seal in the year 2000 (The Doctrine and Covenants 20:1 establishes the correctness of our calendar system since the birth of Jesus), which assures us that there will be a space of time wherein the events spoken of in Revelation 9 will be accomplished.

These events are to take place before the coming of Jesus Christ. How long will it take for these events to occur? The only time periods indicated by holy prophecy during this interval are the amount of time the unnatural locusts will torment the wicked, which is five months; the three and a half years the two prophets will prophesy in Jerusalem before being slain; and the period of silence in heaven for about the space of a half hour that will occur in the seventh thousand years, although John failed to state explicitly how that half hour should be interpreted in terms of Earthly time (Revelation 9:5, 11:3-13. 8:1). This still leaves us to wonder how many more years beyond at least 2003 will the second advent occur. Nevertheless, it does make it clear that the year of the second advent of Jesus Christ will not be at the turn of the millennium, as Perry inferred I stated and believe.

The fact is that no person knows the exact time that Christ will come the second time (Matthew 25:13; The Doctrine and Covenants 49:7). If a person wants to know the time of the impending second coming, I suggest he or she watch for the unfolding events that will surround it. They will serve as warnings that the second coming is about to occur. Other warnings to watch for in addition to the events outlined in Revelation are a great apostasy; The Warning where all humankind will experience a life review simultaneously, to be followed by a great miracle in Garabandal, Spain; the end of the public appearances on Earth by Mary, the Mother of Jesus; a cross in the sky; the disappearance of the rainbow; the moon turning to blood; the surrounding of Jerusalem by armies; a third of humankind slain and those left refusing to repent; and the 
preaching of the gospel to the world and the appearance thereafter of a desolating sickness throughout the world.

What is really sad and depressing is not that many people believe in an end to the world as we know it and that a Millennium of Peace is literal, but rather that some people either will be too involved with the cares of life even to give attention to such things as a second advent of Jesus Christ or will deride such a thing (Luke 21:34; II Peter 3:3-5).

\section{References}

Audette, J. (1982). Visions of knowledge in NDEs. Vital Signs, 1(4), 5-6.

The doctrine and covenants of the Church of Jesus Christ of Latter-day Saints. (1979). Salt Lake City, UT: The Church of Jesus Christ of Latter-day Saints.

Grey, M. (1985). Return from death: An exploration of the near-death experience. London, England: Arkana.

Lundahl, C. R. (1999). Parallels between near-death experience prophetic visions and prophecies from the Bible and Mormon Holy Writ. Journal of Near-Death Studies, 17, 193-203.

Marian Movement of Priests, The. (1996). To the priests, Our Lady's beloved sons. Milo, Italy: Centro Internazionale del M.S.M.

Pearl of great price, The. (1979). Salt Lake City, UT: The Church of Jesus Christ of Latterday Saints.

Ring, K. (1982). Precognitive and prophetic visions in near-death experiences. Anabiosis: The Journal of Near-Death Studies, 2, 47-74.

Ring, K. (1984). Heading toward omega: In search of the meaning of the near-death experience. New York, NY: William Mortow.

Watch and be ready: Preparing for the second coming of the Lord. Salt Lake City, UT: Deseret.

Craig R. Lundahl, Ph.D.

Western New Mexico University 4133 North Huff Street Silver City, NM 88061 